\title{
Mix-use adaptations in sustainable regeneration of barrack complexes
}

\author{
Marta Matgorzata Rudnicka-Bogusz, \\ ${ }^{1}$ Department of History of Architecture, Arts and Technology, Faculty of Architecture, \\ Wrocław University of Science and Technology, Wrocław, Poland
}

\begin{abstract}
Historical barrack complexes constitute a separate genre in architectural typology and a crucial component of cultural landscape in garrison towns. Their construction impacted spatial development of historic cities. Military compounds were usually formed in a raster pattern, which spawned the grid plan further to adjacent streets forming a connection with the existing urban area, thus stimulating growth and modernization of cities. Originally positioned on the outskirts, today they become liaisons between historic downtowns and contemporary suburbs. They are excellently suited for that role, because by default they are utilitarian. Still they are endangered and neglected. For singleminded investors their material substance is worthless compared to the land they stand upon. The Wrzeszcz Barracks give proof that there exists a way to innovatively reintroduce this genre into city scope. Following in the footsteps of European exponents in Turin or Freiburg, the 'Garnizon Neighborhood' is one of the most successful mix-use regeneration efforts of post-military complexes in Poland. The paper constitutes a case study of regeneration indicating its strong and weak points in relation to similar undertakings.
\end{abstract}

\section{Introduction}

Around the world economic, political and technological factors render military facilities redundant. Surplus and obsolete housing and administrative post-military stock are vacated. Buildings in the abandoned defence properties are usually disposed of or extensively redeveloped, rather than recycled within-use. Uninhibited properties often attract social blight: illegal occupancy, vandalism. This may instigate owners to radical actions, including levelling of the property. However, many of post-military complexes include historical architecture, in some cases even monuments. In those instances, razing or complete redevelopment should not be considered an option, as historical buildings constitute elements of cultural

\footnotetext{
*Corresponding author: marta.rudnicka@pwr.edu.pl
} 
landscape, giving proof to history and carrying local tradition. After all, barrack complexes were central to social and economic life of garrison towns [1]. Local authorities supplied infrastructure and roads, sometimes even suitable plots - free of charge. The state financed their construction to manifest its power and wealth, thus embellishing the city. Military compounds were usually formed in a raster pattern, which propagated the grid plan further to adjacent streets forming a connection with the existing urban area, thus stimulating development and modernization of the city. The arrival of the military invigorated local economy. Locals prospered working the construction sites, in catering and services. These immaterial values - local tradition - are immanent to historical army barracks and there is no other way to access those values than to interact with the complexes. History manifests itself as a cultural landscape: the sum of information on all aspects of natural and anthropogenic processes, recorded as a physiognomy of the environment achievable and comprehensible primarily through the sense of sight. As Binder puts it: 'The physical presence of history in everyday life is a necessary psychological reminder of where we come from and where we are headed' [2].

However, recognizing the dynamic nature of living cities, emphasis needs to be put on the integration of historic urban area into local development processes and urban planning, such as, contemporary architecture and infrastructure development [3]. Due to an ever-changing warfare technique, barrack compounds have a limited functional lifespan. Adaptation, either through conversion or within use, is the only sustainable way of dealing with obsolescence. Even UNESCO's 'HUL Recommendation' has recognized the need to 'recycle' the historical architecture, obviously while maintaining highest conservation standards, for the greater good of a sustainable cultural landscape. Therefore, what is needed for post-military historical compounds is a comprehensive adaptive reuse strategy [4].

\section{Obsolescence and adaptation}

To stay in use the building has to keep up with the latest technical and physical standards. Hence, the biggest threat to historical post-military compounds is structural and functional obsolescence. Nonetheless, demolition is in many ways wasteful. While some materials can be salvaged or reused, the embedded energy and cultural connotations are lost. Therefore, drives for building conversion range from scientific, to economic and ecological benefits that come from preserving raw materials [5]. Thus, while market value and usability potential constitute main decision-making factors when assessing the adaptive reuse potential of historical architecture, the cultural-historic value should have primary impact [2]. Already in downtowns of London, Toronto or Melbourne [4], along with Hamburg, Wrocław and Leipzig [6] these values have been recognized and appreciated. Adaptation is seen as a vital part of sustainable development, lending identity to city districts by access to local history.

A sustainable life cycle of a building is perceived as alternation between use and adaptation [7] that can prolong its usability. Still, the greatest value of historical architecture is scientific and sentimental, and these values rely on authenticity, as stated by the 'Charter of Venice'. Therefore, adaptation of historical buildings requires special attention and bears restrictions. For the process of adaptation to be truly sustainable, it must obey some basic guidelines, so that it is reversible and thus 
allows for continuous adaptation. With historical buildings, irreversible alterations should be strictly limited, so as not to thwart the scientific and sentimental value. Still, while some less invasive functions are better suited for implementation in historical architecture, others grant longer lifespan and wider social usability.

The notion of sustainable urban development attracts more and more attention among policymakers, communities and scholars. Maintenance and rehabilitation of buildings and landscapes of cultural and architectural value is currently an essential part of many urban sustainability programs and was endorsed by the 1996 'Istanbul Declaration on Human Settlements' [8]. However, while different national policies require preservation (almost petrification) of cultural heritage, they do not require that all historical architecture be preserved or state how far a refurbishment can go without obliterating the authenticity value. Former defence installations comprise of a great number of diverse buildings: dormitories, tenement houses, mess halls, armouries, stables, workshops, etc. This allows many ways of adaptation. An almost unchanged $18^{\text {th }}$ century Collins Barracks complex today houses a branch of National Museum of Ireland. On the other end of the scope is the MAXXI by Zaha Hadid lodged in a completely remodeled $19^{\text {th }}$ century roman Caserma Montello (Italy). The $18^{\text {th }}$ century Antigones Barracks in Cartagena (Spain) were successfully adapted for the purposes of Polytechnic University of Cartagena. The Austrian Archduke Rudolf's Barracks in Cracow house Cracow University of Technology. The $19^{\text {th }}$ century barracks for Grenadier Regiment of King Wilhelm I in Legnica (Poland) were adapted for the seat of a community college. The functionalist mid- $20^{\text {th }}$ century military dormitories are easily converted into apartments. The 1935 antitank defense unit five-barrack complex - Kaserne Siegeshöhe - in Legnica (Poland) was turned into a residential district. However, assigning a sole role to a historical object may only regenerate it for a short period of time and soon result in a repeated obsolescence. Additionally, it does not solve either the problem of exposure or recognition, needed for propagation of information contained in historical objects.

\subsection{Cultural tourism as a chance of deterring functional obsolescence}

Apart from sustainability of built environment, one of the most important goals of preserving post-defense compounds is educational and scientific. To achieve this goal, the historical architecture must be as authentic as possible and well-exposed. The key here is an able adaptation that facilitates tourism and social activation of the historical premises, without spoiling the feel of authenticity. The compound needs to attract tourism, be accessible and offer educational experience. Elements of cultural landscape need to be safeguarded against potentially destructive actions of tourists, exposed in a clear and educational way and combined with attractive educational aids (preferably multimedia), as well as some side-acts, such as restaurants, shops, etc. The phenomenon of cultural tourism has already been thoroughly researched and explained (to name a few [9-10]) and it provides another reason and means of sustaining such historical compounds. Architecture and landscape architecture constitute an important motivation for travel [11]. However, when it comes to urban destinations, assigning a sole role does not suffice, because it only activates them for short periods of time in specific conditions. Hence, mix-use designs are the best solution, which keeps the investment booming, due to its diversity. Thus, if a regeneration of historical district is designed as mix-use, it can cater to various alternating purposes of a tourist visit, prolonging the functional and economic 
lifespan of historical buildings. The development of cultural tourism (art-, architectural- or urban-tourism [12]) brought about the era of 3E (Entertainment, Excitement, Education) [13]. It also allows a more relaxed approach, when it comes to reconstruction, restoration, anastilosis, etc. of original tissue, which corresponds just fine with historical architecture - not literally considered monument by the law [14]. Tourists flock to reconstructed cultural heritage such as Church of our Lady in Dresden or Market Square in Wrocław even though, based on the date of their completion, they could be classified as contemporary architecture. Nevertheless, most visitors still consider them historical structures. Similar antiquarian appeal could be elicited with right regeneration and exposure of post-military complexes, even if they've been extensively enhanced during adaptation to cater to tourist needs, as proven by the popularity of related field of regeneration of fortified landscapes [15] and manifold social-media outlets related to former defense compounds.

\subsection{Post-military complexes as brownfields}

On the other hand, demand creates supply. Military compounds, originally positioned on the outskirts of municipalities, near railroads, exit routes and shooting ranges, today liaise between historic downtowns and contemporary suburbs. Both the authorities and the investors perceive them mostly as brownfields: a previously developed land, occupied by a permanent structure and fixed surface infrastructure [16]. It is different from vacant land in that its- treatment requires either adaptation of existing structures, decontamination and conversion or levelling and redevelopment of land. In most Polish cities, these post-defence brownfields are still considered a burden, rather than an asset. The value of the existing, obsolete buildings is relatively low and the prospective tenancy in new-build apartment blocks is good. Moreover plots, cleaned of historical architecture, present an opportunity for a more dense development. The conversion potential of structurally obsolete barrack buildings into housing depends on the financial feasibility of such transformation. As in other cases of adaptive reuse, 'the accounted value of structurally vacant buildings is found too high for redevelopers, who calculate land and existing building value residually, as what is left over after subtracting the conversion costs from the total estimated yield of the redevelopment' [4]. After all, as comprehensive studies show [17], not every post-military property can be recycled for civilian use. Contamination, waste and scrap can be a real concern in successful recycling of military brownfields. Luckily, this problem mainly applies to suburban post-military industrial sites, like airports, maintenance facilities or airports. It mostly doesn't concern the compounds consisting of barracks, headquarters and depots. Nonetheless, the author stumbled upon this problem when dealing with regeneration of $19^{\text {th }}$ century Grenadier barrack complex in Legnica (Poland). Part of the plot belonging to the complex was used in the years 1945-1993 as maintenance and repair workshops for military trucks, and soil was contaminated with oil and grease. This constituted a significant problem for an investor, who bought the plot with the intention of building a swimming pool. 


\subsection{Mix-use regenerations: prerequisites and examples}

In consequence, adaptive reuse of historical army barracks results mostly from grassroots initiatives or intervention from the Conservator of Monuments. However, the Conservator is only obliged to safeguard the wellbeing of monuments that are: historic architecture characterized by some outstanding universal value [18] and inscribed in the Register of Monuments. The grassroots initiatives, on the other hand, usually don't have many resources at their disposal. At the same time barrack complexes cover large areas of land and comprise of a great number of various buildings (some historical, others contemporary) and require a specific, holistic approach, which in turn requires urban planning on a regional scale and significant expenses. Also, the comprehensive planning is only possible if the compound hasn't been partitioned. However, the authorities are so eager to get the properties off their books that they are willing to meet most of the investors' demands [19]. In some cases, they simply try to profit from the sale of plots obtained with allowance [20]. Nowadays, it is a common practice to divide larger brownfields in order to effectively sell them. While speeding up the sale, this leads to dissolution of spatial relations between parts held by various owners. It effectively ruins educational utility and touristic appeal of post-military complexes. Historical military complexes form a separate typological genre, with unique hieratic site plans, stately yet austere stylistics and a complex functional program. Thus, a holistic, sustainable approach requires involvement of local government, supervision by the conservator and a significant budget. Taking into account the present state of knowledge, case studies seem to suggest that mix-use adaptations in public-private partnership are the best choice for post-military complexes. Owing to the complexity of the task, we may now witness some highly inventive approaches in architecture and planning, which embrace all these challenges as a chance to experiment with innovative strategies in sustainable urban regeneration. Then again, there are different kinds of sustainable, varying on the rank ascribed to factors like energy consumption, heritage preservation or land use structure.

One approach can be illustrated by the former La Marmora barracks in Via Asti in Turin (Italy). The stately complex, one of the landmarks of the city, is located in the eastern part of Turin, near the historic centre. The complex, built in the years 1887-1888, is composed of six barracks flanking a contemporary depot and a porticoed main edifice. Through the WWII the barracks served fascist regime and the yard was used for executions. During post-war years the complex fell into state of disrepair.
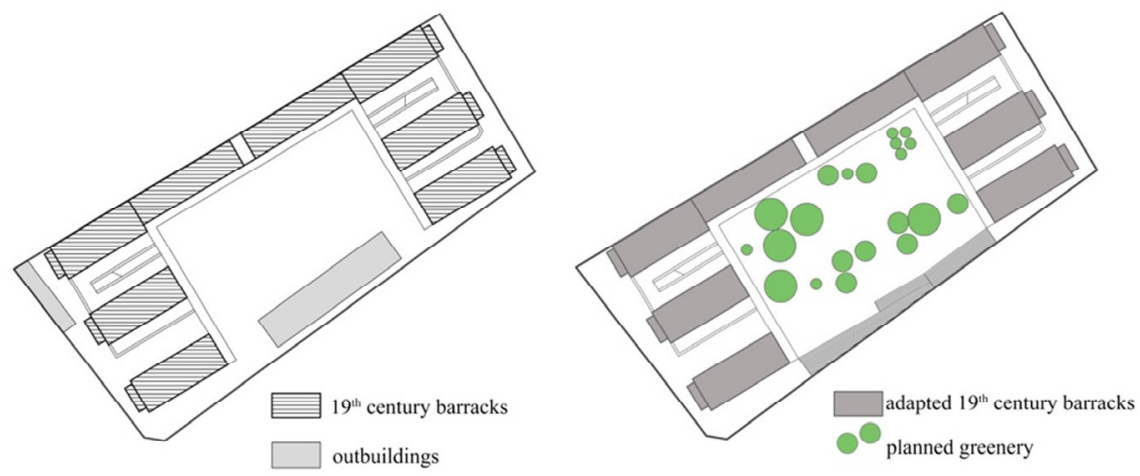

Fig. 1. Figure showing the transformation of Turin La Marmora barracks. 
In 2015 the state undertook regeneration initiative. The urban redevelopment project was designed in cooperation between the studio of Carlo Ratti and the Municipality. The undertaking is also supported financially by state. The concept of regeneration implements residential, commercial and tourist functions in existing historical buildings to create an urban environment for both cultural events, residential and workspace facilities. The residential offer is twofold: a hotel and solutions aimed at young tenants. The workspaces favour start-ups. The linear array of buildings allowed a complimentary distribution of similar functions along one another. The project aims to create a new social hub within the city with shared services and a balanced amount of integrative public and private spaces [21]. The 2 ha complex consists of eight buildings enclosing a vast central courtyard and is a subject to heritage listing since 2004. The state was placed in the position of a curator controlling the aspects of economic feasibility, cultural sustainability, urban quality, etc., with private entrepreneurs acting as the main operators in the arrangement. None of the historical buildings is to be demolished or altered. The only corrections are to take place inside to adjust them to new functions. Also, the urban layout will stay unchanged bolstering the educational value of the regenerated complex.

While the Italian example demonstrates cultural sustainability, the case of Vauban barracks in Freiburg exhibits a regeneration striving towards ecological sustainability. The barracks were built in 1937. The compound consisted of four building complexes, in a linear, oriented array, encompassing four large drill squares. After the WWII, the French army took over the complex and expanded it. It was then renamed Quartier Vauban. After the withdrawal of the French, the compound comprised of 28 large barracks along with numerous outbuildings: garages and depots occupying 38 ha.
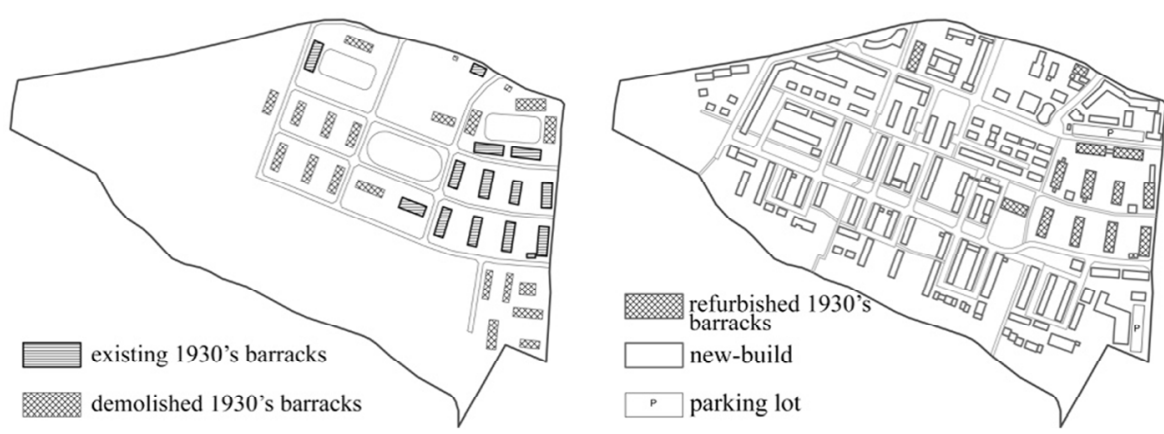

Fig. 2. Figure showing the transformation of barracks in Vauban district.

In 1994 the City Council bought the land from the Federal Government to develop the site as a residential district [22]. Initially the municipality planned to demolish all remaining buildings, however some of them had already been taken over by squatters, who opposed the demolition. Some grassroots civic movements also came forward with the idea for regeneration of the buildings - the vacated barracks were recognized as an opportunity to create affordable living space in the city centre. The authorities decided to retain 6 buildings and convert them into student housing estate. To assure affordable rent and media the buildings were retrofitted with solar panels and thermally insulated. An additional 4 barracks were converted into low-cost housing by the independent housing initiative. 
The buildings were insulated and retrofitted with outer staircases and balconies according to individual tastes of the inhabitants. The nearby edifice at contemporary Alfred Döblin-Platz 1 was turned into a district community centre. The building was insulated and furnished with solar panels. An outer lift grants access to all the floors for the elderly and the disabled. The building at the Lise-Meitner-Straße 12, became a kind of a shared services center combined with a business incubator, allowing entrepreneurs to rent office space with amenities. The outer shell of the building was renovated and the inside partitions were altered to fit the new purpose [23].

It is clear, that both for the social activists and for the City Council the priority was to develop in a participatory way an energetically sustainable, ecofriendly city district with a sustainable service structure. The area is generally car-free. The streets are for pedestrians and bicycles, cars are left in carparks situated at the edge of the estate. City Council sponsored a tramline, to connect the newly established settlement with the rest of the municipality. Most workplaces and homes are within $500 \mathrm{~m}$ radius from public transport network, and all basic services are within a walking distance of apartments. The majority of newly built buildings use solar panels. Tenement buildings all have backyards cultivated for organic crops. From an ecological point of view the district seems to be groundbreaking in terms of sustainability. Nonetheless, out of a total of 28 barracks, only 12 were preserved and furthermore only one was in a relatively unchanged state. The original layout of the 1930's barracks has been completely obliterated - the functionalist barracks were not considered heritage and thus did not enjoy legal protection. All the preservation efforts came from aficionados and grassroots organizations, and their primary objective seemed to be assuring affordable housing in the downtown area.

The military compound at Wrzeszcz was built in the years 1891-1903 west of Gdańsk. The plot was located close to a railway station for an unobtrusive deployment of troops. The main barrack estate occupied ca. 22 ha of land and comprised of about 35 buildings [24] in three complexes: two for cavalry and one for a train battalion. The buildings were splayed on a regular grid plan roughly aligned with cardinal directions. The more presentable office buildings run around the border of the plot adjacent to main streets. Behind them spread out muster yards closed off with dormitories. Farther at the back enormous stable buildings and maneges encompassed inner paddocks and corrals. The complex had a clear spatial composition, in which the axes of the two main roads were separating the three compounds of analogous composition. The buildings were usually two-wing in the type of entre cour et jardin palaces and
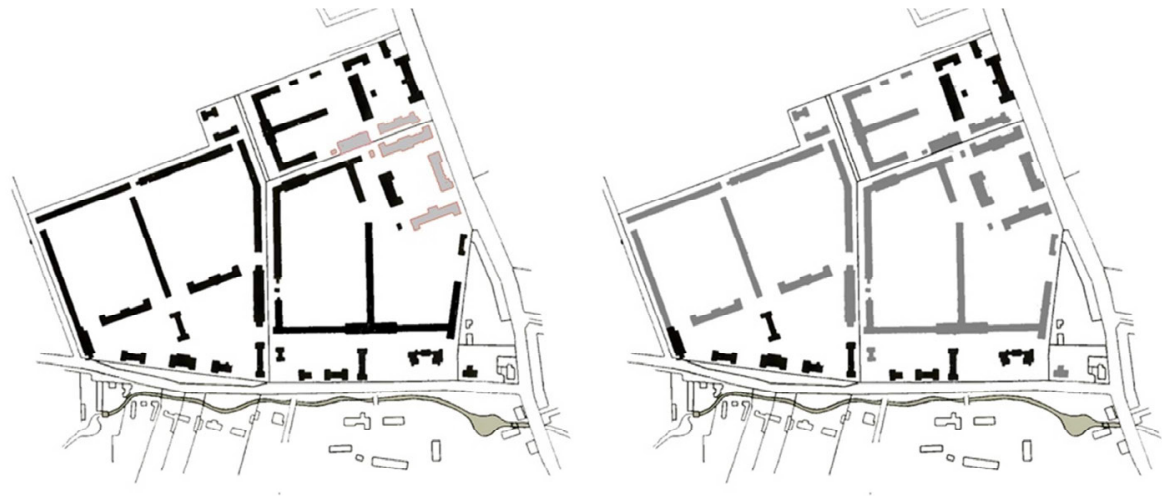

Fig. 3. Figure showing the count of Wrzeszcz complex buildings pre- and post- refurbishment. 
the officer's mess, so-called casino, was a stately villa. They were facilitated with public utilities. The casino even had central heating.

In 2006 a property development company - 'Hossa' - acquired the complex through a public tender. The company perceived the real-estate as a chance to create a composite precinct, with its own centrally placed market, network of services and housing communities. The authorities prepared both the zoning plan and the monument register inscriptions for selected buildings. 'Hossa' fulfilled the injunctions: regenerating all the monuments, keeping up the roads outlining the three complexes, delineating designated muster squares with tree lanes, even preserving some of the buildings, that weren't considered monuments in the light of legal definition. The original stylistics have been maintained or restored, in case of buildings transformed by the previous owner. Adaptation was executed with the use of sophisticated materials - glass and COR-TEN steel - and the necessary thermal insulation was executed with climate boards. Nonetheless, in a present state the educational value of the complex is gone, as none of the three complexes is complete. While most of the residential buildings survive, the outhouses: stables, riding schools, warehouses etc. have all been razed, making way for mix-use new-build.

On the other hand the complex seems to be abuzz at all times, thanks to diverse services housed both in historical and new buildings: offices, shops, restaurants and facilities for cultural, entertainment and creative activities. On entering the premises from the east one is greeted by elevations of renovated ex-dormitories turned office buildings. They encompass a vast muster yard that retains its original characteristics. Behind it lays a newly designed residential district with services on the ground floor. The remaining original residential buildings stand along the southern perimeter of the plot. This part of the compound is today called 'Culture Garrison'. The southwestern compound retains its array more or less, despite the fact that the two northern dormitories have been razed and substituted with tree lanes, making the muster yards unintelligible. The historical buildings currently house services and entertainment a concert hall, a café with a bookshop, boutiques and a dance school. The composition of southeastern compound was distorted when the stalls were demolished. The original buildings are still under refurbishment. The developer plans implementing various 'smart' residential solutions for students of a nearby campus [25].

The revitalization can be considered an economic and PR success. The presence of historic buildings on the premises elevates the prestige of the precinct and allows it to retain its historical connotations. However, one wonders, what would have happened, if the authorities had dreamt bigger. The zoning plan allowed the development company a lot of freedom in creation of the masterplan. The principles of shaping the spatial structure required, among others, representing the course of historical boundaries of the barrack compounds and delineation of selected musteryards. Aside from that, the zoning plan called for removal of the existing buildings and establishing new spatial development. When the development company took over, the complex was almost complete and the original layout clearly intelligible. The heritage conservator described the buildings as well proportioned, functional, with elegant decoration. The document stressed participation of Gdańsk' head architect and town planner Karl Franz Fehlhaber. Yet, only a few objects were formally designated monuments. Others were ignored due to changes executed through the years in either gauge, roof geometry or elevations. This surely seems incomprehensible, as the former defense facility was described as an extraordinary specimen among its kind. Built according to a unified plan it was a hallmark of cultural landscape of the precinct. Its greatest cultural asset was not the esthetic 
value of particular buildings, but its completeness and vastness. With the right public-private partnership, the complex could have been kept in a less altered state and still be economically remunerative for the investor.

\section{Conclusion}

Historical army complexes form a separate heritage genre. In most European countries, planning agencies are unable to draw know-how from similar endeavours, simply because there are no unified national policies. Former garrison towns must adopt a try-and-err approach. At the same time, no coherent information concerning post-military heritage redevelopment is systematically publicised - this area is almost entirely omitted in the academic literature. It is crucial to change this state of affairs, so that local communities - that become stewards of historic complexes and are responsible for creating policies that will prevent both degradation of historical landscape and urban blight - don't get discouraged from nurturing their historical military architecture. Regardless, if the property gets sold to the highest bidder or is transferred free-of-charge, the authorities should take responsibility for harmonious spatial planning. In Poland, usually a local agency receives a property from the state, puts it out to public tender and picks the best offer. Luckily, various arrangements of public-private partnership are also available, and a growing number of authorities appreciate not only a prompt monetary profit, but also other factors, e.g. a potential boost in local economy resulting from increased taxation, diversification of services, as well as activation of previously inaccessible elements of cultural landscape[26].

However, when it comes to urban destinations, assigning a single role does not suffice - it works for short periods of time in specific conditions. Hence, mix-use design is the best solution - it keeps the investment booming and remunerative at all times. If a mix-use regeneration of a historical district can cater to both the needs of residents and tourists, it will prolong the lifespan of historical buildings involved. Selection of the most suitable method of regeneration must always be supervised by the authorities, through a multidimensional study, in close cooperation with the local community. There are various approaches to valorization stemming from different methodologies and motivations. Some complexes will be voted redundant, some necessary and groundbreaking for local identity. Thus, in preserving barrack compounds the Regional Heritage Conservator must play the main role, as best suited for the task. If there is no legal protection and the inherent values are not recognized, the chances for preservation are reduced because only the monument designation places a greater responsibility on the owner.

\section{References}

1. M. Rudnicka-Bogusz, (The architecture and spatial disposition of 19th - and 20th - century military building complexes in Silesia. Typology, design, regenerationpreliminary study, Architectus, 2/42, 19-30 2015)

2. M. Binder, (Adaptive reuse and sustainable design: a holistic approach for abandoned industrial buildings, Master's Thesis, UC, OH, 2003)

3. UNESCO Recommendation on the Historic Urban Landscape

4. S.J. Wilkinson, H. Remøy, C. Langston, (Sustainable building adaptation, Innovations in Decision-making, Willey Blackwell, 2014) 
5. United Nations Environment Program

6. M. Rudnicka-Bogusz, Historyzm jako narzędzie budowania prestizu w XXI wieku, in: J.L. Dobesz, A. Gryglewska, M. Rudnicka-Bogusz (eds), (Nie tylko trony, Wrocław: Oficyna Wydawnicza PWr, 345-352, 2012)

7. I. Cooper, Building Research and Information, 29/2, 158-163 (2001)

8. United Nations Istanbul Declaration on Human Settlements

9. K. Buczkowska, (Turystyka kulturowa. Przewodnik metodyczny, Poznań, Wydaw. AWF w Poznaniu, (2008)

10. G. Richards, (Cultural Tourism. Global and local perspectives, New YorkLondon-Oxford, The Haworth Hospitality Press, 2007)

11. C.R. Goeldner, J.R.B. Ritchie, (Tourism: Principles, Practices, Philosophies. Hoboken, Wiley, 2009)

12. J. Specht, (Towards a New Role Model of the Contemporary Architectural Tourist, in: S. Sonnenburg, D. Wee (eds) Touring Consumption. Management-Culture Interpretation, Springer VS, Wiesbaden, 303-318, 2015)

13. J. Środulska-Wielgus, K. Wielgus, Przestrzeń i Forma, 26, 375-390 (2016)

14. B. Szmygin, (System ochrony zabytków w Polsce - próba diagnozy, in: B. Szmygin (ed.), System ochrony zabytków w Polsce - analiza, diagnoza, propozycje, Lublin, 7-16, (2011)

15. Z. Myczkowski, K. Wielgus, J. Środulska-Wielgus, W. Rymsza-Mazur, K. Chajdys, Wiadomości Konserwatorskie, 23, 36-58 (2008)

16. S. Bagaeen, C. Clark, (Sustainable Regeneration of Former Military Sites, Routledge (2017)

17. K.N. Hansen, (The Greening of Pentagon Brownfields: Using Environmental Discourse to Redevelop Former Military Bases, Lanham, MD: Lexington Books, (2004)

18. Convention Concerning the Protection of the World Cultural and Natural Heritage adopted by The General Conference of UNESCO on 16 November 1972

19. M. Szczepański, (Życie po J.A.R. 10-lecie programów zagospodarowania mienia przejętego od wojsk Federacji Rosyjskiej, Rada Programowa do Zagospodarowania Przejętego Mienia i Rekultywacji Terenów Zdegradowanych przez Wojska Federacji Rosyjskiej, Warszawa, (2005)

20. W. Jarczewski, M. Kuryło, (Rewitalizacja terenów powojskowych, in: W. Jarczewski (ed.), Przestrzenne aspekty rewitalizacji - śródmieścia, blokowiska, tereny poprzemystowe, pokolejowe i powojskowe, Kraków, 243-288, (2009)

21. C. Coscia, C. Senatore, (Defense heritage: strategies for disposal and use. The case of the 'La Marmora' Barracks in Via Asti, Turin, in: P. Argenziano, et all (eds.) World Heritage and Disaster. Knowledge, Culture and Representation, Napoli, 199-208, (2017)

22. http://www.josephlittlearchitects.com/articles/baugruppe-lessons-freiburgcooperative-housing/

23. http://www.vauban-im-bild.de

24. H. Dublanski, W. Rohlfing, (Militärbauten in: R. Kohnke (ed.), Danzig und seine Bauten herausgegeb. v. Westpreussischen Architekten und Ingenieur-Verein zu Danzig, Berlin, 115-134, (1908)

25. An interview with the representative of Hossa conducted on the 6.02.2018

26. M. Doussard, Economic Development Quarterly, 28/ 4, 339-350 (2014) 